\title{
Assessment of Community Vulnerability to Riverbank Erosion in Esperanza, Agusan Del Sur, Philippines
}

\author{
Lenard P. Dapar', Glenn Arthur A. Garcia², Allyssa G. Mandras', \\ Maricel M. Balo' and Chime Mora-Garcia ${ }^{2}$ \\ ${ }^{1}$ College of Arts and Sciences, Caraga State University \\ ${ }^{2}$ College of Agricultural Sciences and Natural Resources, Caraga State University
}

\section{ABSTRACT}

As a natural phenomenon, most rivers constantly undergo a series of erosion processes along their banks. Erosion, could be triggered by anthropogenic activities. This study assessed the vulnerability of selected communities in the Municipality of Esperanza, Agusan del Sur, Philippines in response to prevalent riverbank erosion at Wawa river. This study partly used the Livelihood Vulnerability Index (LVI) and also used a structured interview schedule to gather information about the socio-economic characteristics, distance of houses and agricultural lands from the river, and practices and strategies against riverbank erosion. Information gathered were categorized into sensitivity, exposure and adaptive capacity. Results showed that barangay Crossing Luna was most vulnerable in terms of sensitivity and exposure while Piglawigan was more vulnerable in terms of adaptive capacity. On the other hand, riverbanks of barangay Dakutan and Crossing Luna are more vulnerable to erosion. In general, Crossing Luna was found to be the most vulnerable among the three communities with a combined index of 0.02 . The study also showed that the LVI is a relevant tool for decision making in determining which community needs most help in times of calamity due to riverbank erosion.

Keywords: adaptive capacity, exposure, riverbank erosion, sensitivity, vulnerability, Livelihood Vulnerability Index

\section{INTRODUCTION}

Soil erosion is known to have detrimental effects on the environment and economy most especially for agriculture. It results in the loss of topsoil thereby affecting soil fertility and changing some of the physico-chemical properties of the soil. Removal of topsoil washes away nutrients and organic matter and may significantly reduce crop yield. Soil erosion generally occurs on steep slopes in upland areas where farmers are practicing inappropriate cultivation techniques. Another form of erosion is

Correspondence: G.A.A. Garcia. Address. College of Agricultural Sciences and Natural Resources, Caraga State University, Ampayon, Butuan City, Philippines.Email: gartgarcia@yahoo.com Tel. no.: (086) 341 2786 local 147

DOI: $10.32945 /$ atr38210.2016 
continuously occurring along the riverbanks. Rivers are dynamic systems as they are constantly changing and their banks are most susceptible to erosion since the soil is always in contact with water. Riverbank erosion could occur naturally such as in concurrence with flooding or as the aftermath of flood (Aktar, 2013). The same process could also be influenced by human activities since land use and stream management can also trigger erosion responses (Dutta and Chakroborty, 2013).

Soil erosion is prevalent in the periphery of the riverbank of Agusan River which is considered as one of the largest river basins in the Philippines. In the municipality of Esperanza, Agusan del Sur, Wawa river, which is one of the many tributaries of Agusan River, is constantly engaging the natural process of riverbank erosion. The periphery of the river is constantly being eroded as an effect of its natural process of change. The natural process of riverbank erosion can produce unfavorable outcomes such as degradation and lessening the space of agricultural lands that are situated close to the vicinity of the river, reduce crop productivity, worsen water quality and destroy adjacent habitats for different plant and animal species including that of the human habitats. The community of Dakutan, Crossing Luna and Piglawigan are relying heavily on the lands that are close to the river for settlements and agricultural farm which serve as their livelihood. The occurrence of soil erosion in riverbanks is highly detrimental to the residents that badly need some solution. Erosion is more likely to occur at the onset of heavy rainfall and floods. Most vulnerability studies are more focused on the holistic impacts of climate change and only few researches are aimed in determining vulnerability of communities to specific natural calamities such as erosion. Thus this study was conducted to assess the vulnerability of the community to riverbank erosion along the riverbanks of Wawa river in Esperanza, Agusan del Sur.

This study partly used the Livelihood Vulnerability Index (LVI) by Hanh et al. (2009). The index is easy to compute because with the exception of precipitation and temperature data, it uses primary data from household respondents. The LVI was drawn from Sustainable Livelihoods Approach (SLA) to development analysis (Chambers and Conway 1992), according to which communities are described in terms of their natural capital, social capital, financial capital, physical capital, and human capital (Simane et al. 2016). Further, it reorganizes the SLA into new categories, which include an explicit climate component, and is constructed in a manner amenable to the use of household survey data. Several variables are used to capture the level of exposure to natural disasters, adaptation capacity of households and their sensitivity to riverbank erosion. LVI does not only capture the susceptibility to droughts and floods but also takes into account the current vulnerability which is useful for environmental planning (Hanh et al. 2009). It also incorporates the vulnerability indicators as defined by the Intergovernmental Panel for Climate Change (IPCC). According to Parry et al. (2007) vulnerability is a function of the character, magnitude, and rate of climate change and variability to which a community is exposed, its 
sensitivity, and its adaptation capacity. The findings of the study are crucial to the community especially to the households residing near Wawa river since this will provide insights to the residents pertaining to the extent of the vulnerability of their settlements and agricultural lands to riverbank erosion. This can also help the Local Government Unit (LGU) of Esperanza, Agusan del Sur in decision making and policy formulation in prioritizing the protection and stabilization of riverbanks to minimize the impact of erosion to the community.

Using the LVI, this study determined the socio-economic characteristics, distance of houses and agricultural lands from the river, and practices and strategies against riverbank erosion for the three barangays that lay successively in Wawa River. Specifically it, determined the vulnerability of the community in terms of sensitivity, exposure and adaptive capacity; and compares the vulnerability indices of the three barangays (villages).

\section{METHODOLOGY}

\section{Household survey}

The study was conducted in the municipality of Esperanza, Agusan del Sur. The three selected barangays were Crossing Luna, Dakutan, and Piglawigan which lay successively along Wawa River that is continually engaging the process of erosion (Figure 1). A household survey was conducted making use of an interview schedule to gather the necessary data with respect to the community's sensitivity (livelihood and revenue), exposure (distance of houses and agricultural land from the river, and adaptive capacity (socio-demographic characteristics, practices, strategies and displacement capability) to riverbank erosion. A total of 279 household members were randomly chosen and interviewed in this study. One member per household was interviewed provided that the respondent was at least 18 years of age and knows the basic information of their livelihood. Results of the survey were quantified and scaled using the LVI and were plotted in a radar diagram.

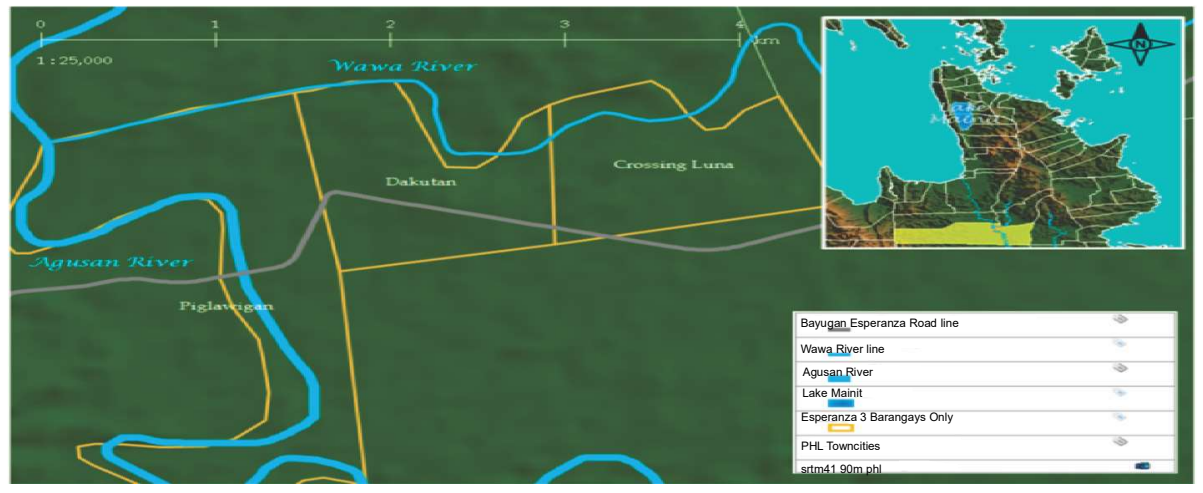

Figure 1. Map of the study area and Wawa River in Esperanza, Agusan Del Sur 
Vulnerability Analysis

This study partly adopted the Livelihood Vulnerability Index (LVI) developed by Hahn et al. (2009) as a basis for the vulnerability analysis. The LVI was partly adopted since it has seven major components which included socio-demographic profile, livelihood, health, social networks, food, water, and finally natural disasters and climate variability but only few major components was included in the study and subcomponents were modified. Vulnerability assessment tools for ecosystems are important to achieve natural ecosystems conservation's goal and at the same time offer effective management and planning solutions to minimize destructive impacts of stressors (Luers et al. 2003). However, there were no recent studies which made use of the LVI for assessing vulnerability to soil erosion and some part of its quantification process was used in this study. Some part of the process was modified to complement with the data that were gathered. The LVI that was used also incorporates IPCC vulnerability which is used to assess vulnerability to climate change and variability. The major components of the IPCC vulnerability are sensitivity, exposure, and adaptive capacity. Each component is made of several indicators which were measured in different scales. It is therefore necessary to standardize each as an index using the equation:

$$
\text { IndexSr }=\frac{S r-S \min }{S \max -S \min }
$$

Where $S_{r}$ is the subcomponent indicator for the region $(r)$, and $S_{\min }$ is the minimum value and the $S_{\max }$ is the maximum value. The indicators where then averaged to obtain the index of each major component using the equation:

$$
M r=\frac{\sum_{i=n}^{n} \text { index } S r}{n}
$$

Where $M_{r}$ is one of the major components for region, index $\mathrm{Sr}$ represents the subcomponents indexed by $\mathrm{i}$ that make up each major component, and $\mathrm{n}$ is the number of subcomponents in each major component.

Once exposure, sensitivity, and adaptive capacity were calculated, the three contributing factors are combined using the equation:

$$
L V I r=(M r E-M r A) \times M r S
$$

Where $\mathrm{LVI}_{\mathrm{r}}$ is the livelihood vulnerability index for the region, $\mathrm{M}_{\mathrm{r}} \mathrm{E}$ is the exposure score for the region, $\mathrm{M}_{\mathrm{r}} \mathrm{A}$ is the adaptation capacity score for the region, and $\mathrm{M}_{\mathrm{r}} \mathrm{S}$ is the sensitivity score for the region.

The LVI is scaled from -1 as least vulnerable to 1 as most vulnerable. Using the LVI model, each major component was scaled and plotted in a vulnerability triangle. 


\section{RESULTS AND DISCUSSION}

\section{Sensitivity}

Socio-economic characteristics such as livelihood and revenues are the basis for the determination of sensitivity of the community. Majority of the respondents are self employed but other family members are also working to help augment their income (Table 1). These are respondents who are earning small amount of income as tricycle driver, farmer, laborer and among others. A respondent whose means of income is farming depends mostly on their produce and has no alternative livelihood activities. This is primarily the most sensitive members in the community since they are just earning a meager income, enough for their daily expenses and could hardly save any amount to be allocated for emergency situations. Most of the respondents in Dakutan and Piglawigan have a monthly income ranging from 5,000-10,000 pesos while respondents in Crossing Luna earns below $3,000(44.1 \%)$. This would mean that Crossing Luna would be most sensitive in terms of income since they have the most number of household with low amount of earnings implying that they have few resources or nothing at all to use in responding and recovering from natural disasters like erosion. If flood and riverbank erosion affect them, they tend to cope up less than those having higher income. Because of their low income, they also would have narrow access to financial loans which are necessary for them to cope and recover from any natural disasters and emergency situations.

\section{Exposure}

Distances of houses as well as the distance of agricultural land from the river are the basis for the determination of the degree of exposure of the community from soil erosion. Crossing Luna has the most (61.3\%) number of established houses located closer to the river. These houses situated less than 50 meters from the river are deemed more vulnerable since they are more exposed to inundation of the river and has a higher chance of being affected by soil erosion along the bank. Hence, this barangay entails higher degree of vulnerability since they are more exposed to the threats of erosion. The presence of housing and other buildings very close to surface water bodies and the lack of appropriate building and planning standards/codes can essentially increase the damage and destruction to infrastructure and property besides taking its toll on the human population (Srinivas and Nakagawa, 2008). Most of the houses surveyed in the three barangays were made of light materials utilizing nipa as roofing materials, bamboo for floorings, and plywood for walls and ceiling. This type of houses is all that the respondents could afford to build since their income is not sufficient for them to purchase cements and hollow blocks to build concrete houses. Type of construction material, the structural 
Table 1. Indexed sub-components and overall LVI for the Dakutan, Crossing Luna, and Piglawigan in Esperanza, Agusan del Sur

\begin{tabular}{|c|c|c|c|c|c|c|c|}
\hline $\begin{array}{l}\text { IPCC } \\
\text { Contributing } \\
\text { Factors to } \\
\text { Vulnerability }\end{array}$ & Sub-Component & Dakutan & $\begin{array}{l}\text { Crossing } \\
\text { Luna }\end{array}$ & Piglawigan & Dakutan & $\begin{array}{l}\text { Crossing } \\
\text { Luna }\end{array}$ & Piglawigan \\
\hline \multirow[t]{5}{*}{ Sensitivity } & $\begin{array}{l}\text { Percent of household heads that are self- } \\
\text { employed }\end{array}$ & 67.7 & 86 & 76.3 & \multirow[t]{5}{*}{0.4344} & \multirow[t]{5}{*}{0.5018} & \multirow[t]{5}{*}{0.4451} \\
\hline & $\begin{array}{l}\text { Percent of household with more than one working } \\
\text { member }\end{array}$ & 54.8 & 60.2 & 50.5 & & & \\
\hline & $\begin{array}{l}\text { Percent of households with income less than or } \\
\text { equal to } 3,000 \text { per month }\end{array}$ & 28 & 44.1 & 24.7 & & & \\
\hline & $\begin{array}{l}\text { Percent of household dependent solely on } \\
\text { agriculture as a source of income }\end{array}$ & 58.1 & 57 & 67.7 & & & \\
\hline & $\begin{array}{l}\text { Percent of household dependent on farm produce } \\
\text { for food }\end{array}$ & 8.6 & 3.2 & 3.2 & & & \\
\hline \multirow[t]{8}{*}{ Exposure } & $\begin{array}{l}\text { Percent of houses established less than } 50 \text { meters } \\
\text { from Wawa river }\end{array}$ & 16.1 & 61.3 & 5.4 & \multirow[t]{8}{*}{0.3787} & \multirow[t]{8}{*}{0.4671} & \multirow[t]{8}{*}{0.3703} \\
\hline & Percent of houses made of light materials & 62.4 & 65.6 & 72 & & & \\
\hline & Percent of houses with poor building condition & 12.9 & 8.6 & 18.3 & & & \\
\hline & $\begin{array}{l}\text { Average number of years since the house was } \\
\text { constructed }\end{array}$ & 17.9 & 17.3 & 18.3 & & & \\
\hline & $\begin{array}{l}\text { Percent of household affected by riverbank } \\
\text { erosion }\end{array}$ & 45.2 & 72 & 26.9 & & & \\
\hline & Percent of household affected by floods & 94.6 & 100 & 99 & & & \\
\hline & $\begin{array}{l}\text { Percent of agricultural lands situated less than } 50 \\
\text { meters from Wawa river }\end{array}$ & 25.8 & 36.6 & 23.7 & & & \\
\hline & $\begin{array}{l}\text { Percent of agricultural lands affected by riverbank } \\
\text { erosion }\end{array}$ & 17.2 & 9.7 & 21.5 & & & \\
\hline
\end{tabular}


Table 1. Continuation

\begin{tabular}{|c|c|c|c|c|c|c|c|}
\hline $\begin{array}{l}\text { IPCC } \\
\text { Contributing } \\
\text { Factors to } \\
\text { Vulnerability }\end{array}$ & Sub-Component & Dakutan & $\begin{array}{l}\text { Crossing } \\
\text { Luna }\end{array}$ & Piglawigan & Dakutan & $\begin{array}{l}\text { Crossing } \\
\text { Luna }\end{array}$ & Piglawigan \\
\hline \multirow[t]{5}{*}{$\begin{array}{l}\text { Adaptive } \\
\text { capacity }\end{array}$} & $\begin{array}{l}\text { Percent of households that has no actions to prevent soil } \\
\text { erosion }\end{array}$ & 58.1 & 33.3 & 50.5 & \multirow[t]{5}{*}{0.4752} & \multirow[t]{5}{*}{0.4258} & \multirow[t]{5}{*}{0.5397} \\
\hline & $\begin{array}{l}\text { Percent of household that has no farming strategies to } \\
\text { cope with erosion }\end{array}$ & 25.8 & 34.4 & 50.5 & & & \\
\hline & $\begin{array}{l}\text { Percent of household that are not concerned in } \\
\text { protecting the riverbank from erosion }\end{array}$ & 2.1 & 1.1 & 1.1 & & & \\
\hline & $\begin{array}{l}\text { Percent of households affected by riverbank erosion that } \\
\text { has no plan to migrate to less vulnerable areas }\end{array}$ & 77.4 & 74.2 & 90.3 & & & \\
\hline & $\begin{array}{l}\text { Percent of households that have no place for relocation } \\
\text { in case erosion or disaster will occur }\end{array}$ & 74.2 & 69.9 & 77.4 & & & \\
\hline LVI & & & & & $\overline{0.04194}$ & 0.02071 & -0.07542 \\
\hline
\end{tabular}


features of the construction and in some cases the occupancy and use of houses play an important role in decreasing the physical vulnerability of houses and infrastructure (Tingsanchali, 2012). Almost all of the respondents mentioned that they are affected with floods at the onset of a heavy and prolonged rainfall. Occurrence of flood is caused when there is overbank flow and on the average happens every one to two years. Agricultural lands which are also situated less than 50 meters from the river are more vulnerable and Crossing Luna has shown the higher degree of exposure since they have (36.6\%) agricultural lands situated near the vicinity of the river. Crops planted in these areas will be affected especially when it is ready for harvesting. This in turn will affect the socio-economic conditions of the people in the community making them more vulnerable.

\section{Adaptive Capacity}

Socio demographic profile, household's practices, farming strategies and displacement capability to cope with the risk of riverbank erosion are the basis for the determination of community's adaptive capacity. Most of the respondents belonged in the middle age group ranging from 31 to 60 years old accounting for $62.4 \%$ in Dakutan, $66.7 \%$ in Crossing Luna, and $77.4 \%$ in Piglawigan. Age is a significant factor for household vulnerability since younger members are more flexible and capable to cope with any disaster that may happen as compared to older household members which could just be a burden. In terms of gender composition, Piglawigan has the highest number of male members (49.5\%) in the family followed by Crossing Luna (37.6) and Dakutan (34.4\%). On the other hand, female household members dominates in Dakutan (65.6\%) compared to Piglawigan and Crossing Luna. Male members are assumed to be stronger and flexible than female members. Hence, male members can have the capacity to cope with any stressors. In addition, the community which has high female members can be more vulnerable compared to community having less female members. But the study of Ajibade et al. (2013) concluded that gender alone is not a significant determinant of vulnerability but will also include gender relations and gender roles with class, place, employment status and social entitlement such as health care. Women can be resilient to disasters provided they belong to middle or upper class, have a good occupation, and have access to health care.

Majority of the respondents were not able to study college since most of them have only reached high school level. However, there were some respondents from Barangay Dakutan and Crossing Luna that pursued and graduated from college (4.3\%). In addition, there were also illiterate individuals in Dakutan (1.1\%) and Crossing Luna (2.2\%). As a factor which can contribute to vulnerability, information pertaining to coping strategies can mostly be gained through education but lacking proper education can increase vulnerability. Knowledge of the risk of flood and riverbank erosion is determined by how familiar the community is in responding to 
emergencies brought by natural disasters. As such, flood and erosion warning systems can be communicated properly to the communities by sending warning dissemination to people.

To cope with the risk, households must have practices or strategies to prevent soil erosion along the river. Among their practices for erosion prevention are planting trees and making barriers along the bank. Majority of the households in Dakutan (58.1\%) and Piglawigan (50.5\%) do not have any practices employed to prevent riverbank erosion, while those living in Crossing Luna (59.1\%) are mostly planting trees. Riverbank stabilization could be cost-effective through ecological restoration and developing riparian vegetation. The study of Li et al. (2006) proved that employing simple ecologically sustainable and socio-economically beneficial methods for restoring riverbanks can significantly reduced erosion, along with an increase in species and habitat diversity, and improve aesthetics and water quality.

On the other hand, most households are engaged in agricultural activities near the river, but majority of the farmers have no strategies to minimize riverbank erosion (Figure 2). This is in contrast to their view that they are concerned about protecting their riverbanks but less action is done to mitigate the problem. Most farmers from Piglawigan (50.5\%) do not have coping strategies in farming that could mitigate the problem of riverbank erosion and this is followed by farmers from Crossing Luna (34.4\%) and Dakutan (25.8\%), respectively. Several factors probably would affect why farmers have no concern in preventing soil erosion from happening. The study of Illukpitiya and Gopalakrishnan (2004) mentioned that farmers will adopt erosion-control practices if there are implementation tools such as education, subsidies, and technical assistance while their low willingness to invest in soil conservation indicates the necessity for public installation of conservation structures

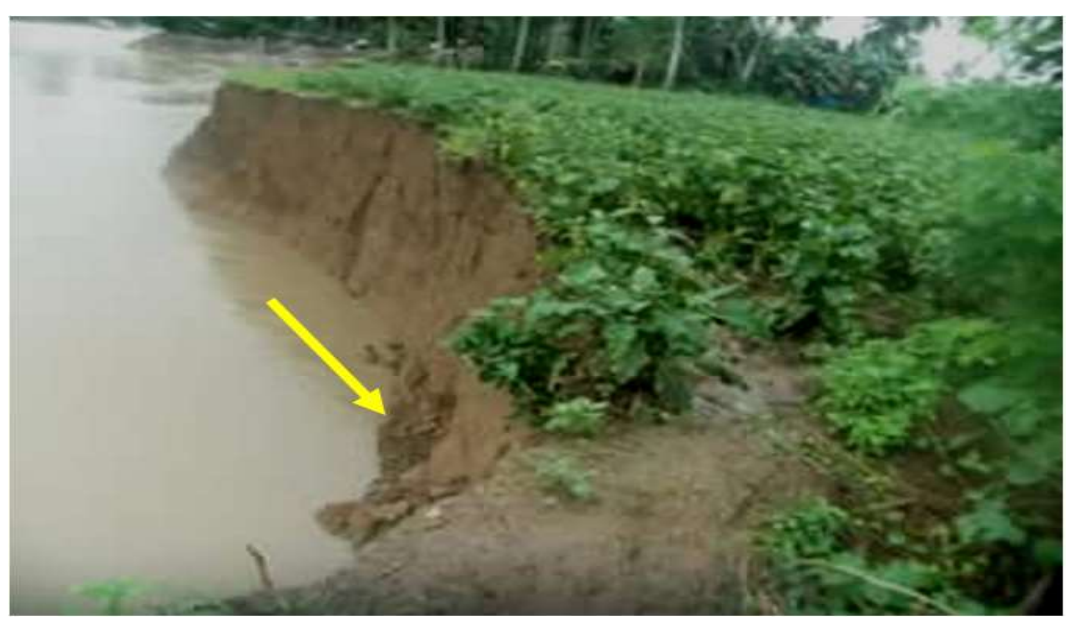

Figure 2. Riverbank in Brgy. Dakutan along Wawa River affected by soil erosion 
A household has to exercise preparedness when disaster strikes. To cope with hard situation, a household must have a place for relocation in times when there is erosion or flood along the riverbanks especially during long rainy seasons where bank erosions are prevalent. The results indicate that most of the respondents especially from Piglawigan do not have a relocation area at the outset of a disaster. If flood occurs, most of them will just wait for the water to subside and stay inside their house provided that the water do not reach and enter their house. Most do not mind the threat of erosion since they deem it as less likely to happen in their area.

\section{Vulnerability Analysis}

The results from the scale of each major component as well as the LVI measured scales are presented in vulnerability triangle as shown in Figure 3. Results showed that Crossing Luna is the most vulnerable in terms of sensitivity with a scale of 0.50 followed by Piglawigan and Dakutan at 0.44 and 0.43 , respectively. Since most households in Crossing Luna have the most number of self employed with meager amount of income, the people in this area appear to be the most vulnerable in terms of sensitivity. Income could influence the household's contingency in coping up after a disaster which means that better off households are expected to respond well compared to poorer households.

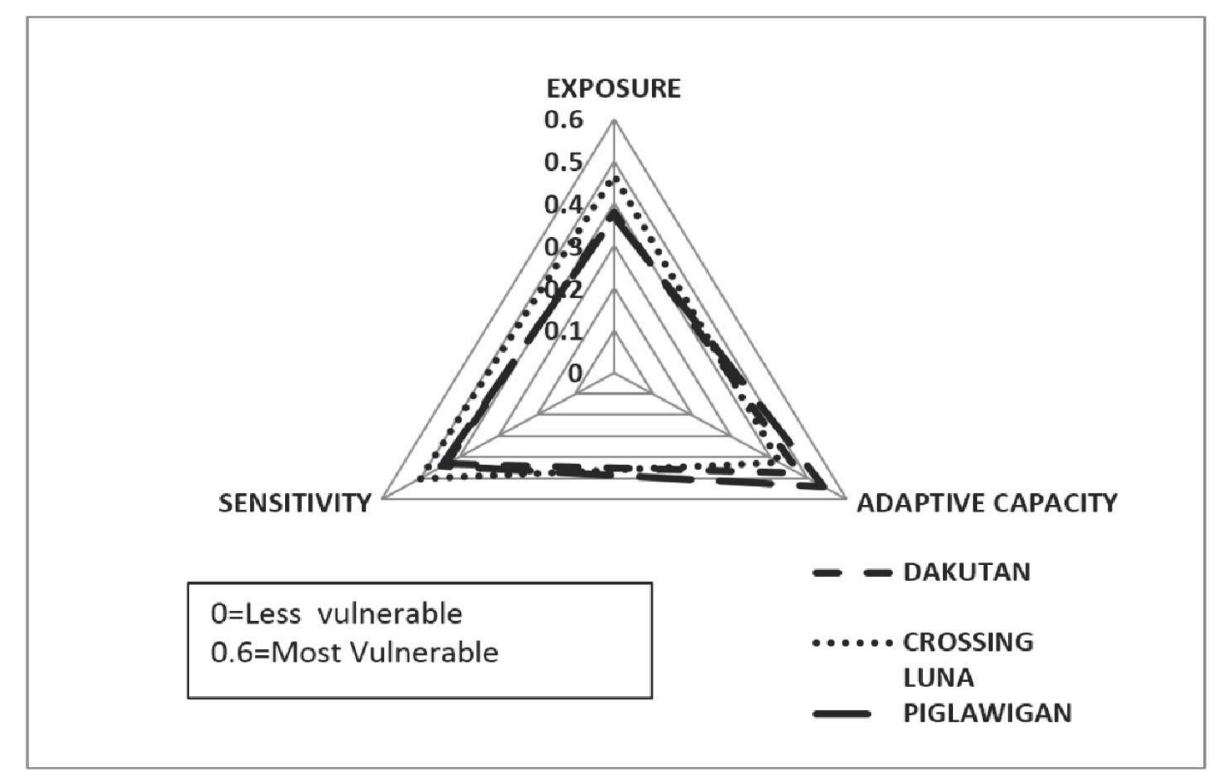

Figure 3. Vulnerability triangle for the three major components of LVI in the three barangays of Esperanza, Agusan del Sur

In terms of exposure, Crossing Luna is the most vulnerable with a score of 0.46 followed by Dakutan having 0.37 score and Piglawigan as the least vulnerable (0.36). This could be because Crossing Luna has the most 
number of household and agricultural lands that are more exposed to soil erosion situated closer to the vicinity of the river.

In terms of adaptive capacity, Piglawigan is deemed more vulnerable among the three barangays with a scale of 0.54.Piglawigan does not employ farming strategies that could reduce soil erosion. Most household do not have displacement capability since they do not have relocation sites in case floods riverbank erosion occurs especially at the onset of a flood.

To compare the overall rank of the three barangay into its level of vulnerability, Figure 4 provides the integrated results for LVI scale plotted in radar diagram. Result shows that Crossing Luna is the most vulnerable having a scale of 0.02 . This is followed by Dakutan having -0.041 scale and Piglawigan as the least vulnerable with a scale of -0.07 . This implies that Crossing Luna should be given priority by its local leaders since it is the community that needs more assistance to lessen its vulnerability against riverbank erosion and other natural disasters that may occur. The results also emphasize that sources of vulnerability are important because specific policy tools may be needed to deal with different aspects of vulnerability. For example, specific interventions may be required to reduce sensitivity, whereas others may help build adaptive capacity (Cinner et al. 2012) or reduce the exposure by mitigating threats of riverbank erosion. To reduce vulnerability, it is therefore imperative to improve the environmental and economic condition of the society. To be able to be resilient and respond automatically to any stressors, the level of awareness in terms of different practices and strategies must be intensified to prevent further erosion that might happen especially in Crossing Luna which is most vulnerable. This should be in coordination with LGU and that they should implement mitigating measures in terms of coping from the risk of erosion.

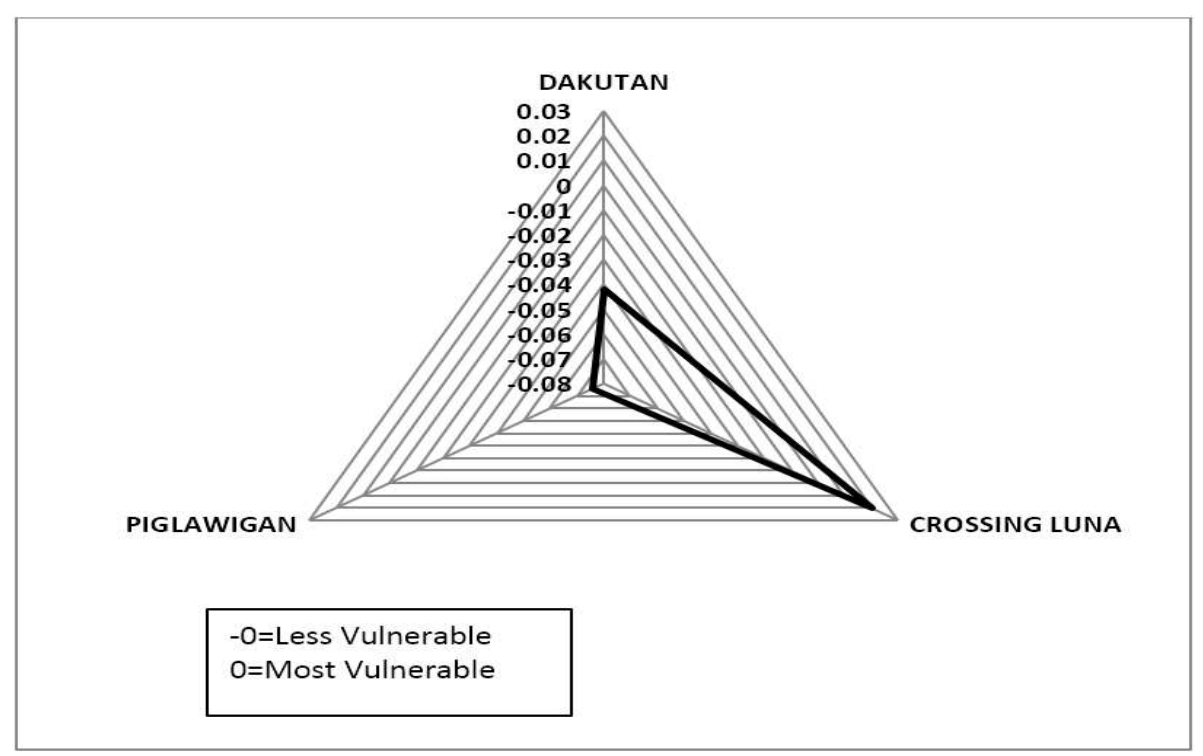

Figure 4. Overall livelihood vulnerability index triangle diagram for the three barangays in Esperanza, Agusan del Sur 


\section{CONCLUSION}

Crossing Luna was found the most vulnerable in terms of sensitivity and exposure since most of the respondents are self employed with lower amounts of earnings. Furthermore, it also appeared the most vulnerable in terms of exposure since most of its household and agricultural lands are situated near the river. Piglawigan was most vulnerable in terms of adaptive capacity since most of its households do not employ strategies that could cope with erosion and most households do not have relocations or evacuation centers if ever disaster will occur. Based on the overall index, Crossing Luna was the most vulnerable among the three communities. Majority of the farmers from the three barangays do not have farming strategies as well as household practices that could cope with the erosion. Hence, the LVI captures the main characteristics of different communities susceptible to riverbank erosion and identifies the priorities needed to reduce the vulnerability. Therefore, it is a relevant tool for decision making in determining which community needs help in terms of its vulnerability to riverbank erosion and other kinds of natural disaster. Since the study focused only on components that are influenced by household assets, there is some level of subjectivity in choosing various indicators. As such, captured data need to be further updated or improved when conditions in the study site change.

\section{REFERENCES}

AJIBADE, I., G. McBEAN and R. BEZNER-KERR. 2013. Urban flooding in Lagos, Nigeria: Patterns of vulnerability and resilience among women. Global Environmental Change 23:1714-1725

AKTAR, N. 2013. Impact of climate change on riverbank erosion. International Journal of Sciences: Basic and Applied Research 7(1):36-42

Chambers R., and G. Conway. 1992. Sustainable Rural Livelihoods: Practical Concepts for the 21st Century, IDS Discussion Paper 296. IDS, Brighton, UK, pp 33

CINNER, J.E., T.R. MCCLANAHAN, N.A.J. GRAHAM, T.M. DAW, J. MAINA, S.M. STEAD, A. WAMUKOTA, K. BROWN, AND 0. BODIN. 2012. Vulnerability of coastal communities to key impacts of climate change on coral reef fisheries. Global Environmental Change 22:12-20

DUTTA, K AND S. CHAKROBORTY. 2013. Human aspects of river bank erosion: a case study of Khairkata Village, Diana River Basin , Jalpaiguri, West Bengal. Geo-Analyst 1:82-93

HAHN B. M., A.M. RIEDERER, and S.O. FOSTER. 2009. The livelihood vulnerability index: A pragmatic approach to assessing risks from climate variability and change-a case study in Mozambique. Global Environmental Change 19:74-88

ILLUKPITIYA, P. and C. GOPALAKRISHNAN. 2004. Decision-making in soil conservation: application of the behavioral model to potato farmers in Sri Lanka. Land Use Policy 21(4):321-331 
LI, X., L. ZHANG, and Z. ZHANG. 2006. Soil bioengineering and the ecological restoration of riverbanks at the Airport Town, Shanghai, China. Ecological Engineering 26(3):304-314

LUERS A. L., D.B. LOBELL, L.S. SKLAR, C.L. ADDAMS, and P.A. MATSON. 2003 A method for quantifying vulnerability, applied to the Yaqui Valley, Mexico. Global Environmental Change 13:255-267.

PARRY, M.L., O.F. CANZIANI, J.P. PALUTIKOF, P.J. VAN DER LINDEN, and C.E. HANSON. 2007. Contribution of Working Group II to the Fourth Assessment Report of the Intergovernmental Panel on Climate Change. Cambridge, UK, pp. 976.

SIMANE, B., B. F. ZAITCHIK AND J. D. FOLTZ. 2016. Agroecosystem specific climate vulnerability analysis: application of the livelihood vulnerability index to a tropical highland region. Mitigation and Adaptation Strategies for Global Change 21(1): 39-65

SRINIVAS, H. and Y. NAKAGAWA. 2008. Environmental implications for disaster preparedness: Lessons learnt from the Indian Ocean Tsunami. Journal of Environmental Management 89:4-13

TINGSANCHALI, T. 2012. Urban flood disaster management. Procedia Engineering. 32:25-37 